\title{
Effect of Spacing and Nutrients Management on Growth, Yield, Yield Attributes and Quality Characters in Hirsutum Cotton of Central Plain Zone of U.P. India
}

\author{
Avinash Kumar Singh ${ }^{1}$, Jagdish Kumar ${ }^{1}$, Rajeev Kumar ${ }^{2}$, \\ Sudhir Kumar $^{3 *}$ and Sunil Kumar ${ }^{1}$ \\ ${ }^{1}$ C.S. Azad University of Agriculture and Technology, Kanpur, India \\ ${ }^{2}$ Central Warehousing Corporation New Delhi, India \\ ${ }^{3}$ Department of Entomology, Sardar Vallabhbhi Patel University of Agriculture and Technology, \\ Meerut- 250110 (U.P.), India \\ *Corresponding author
}

\section{A B S T R A C T}

Cotton is one of the most commercial crops of the world and in the maintaining of many economics. Cotton is cultivated in nearly 100 countries with China, India, United States, Pakistan and Brazil being the five largest producers of cotton. Cotton is the back born of textile industry and provides raw material in the form of lint to the textile industry. A field experiment was conducted, with hirsutum cotton genotype H-1300 during Kharif season 2015 at the Oil Seed Farm of C.S. Azad University of Agriculture and Technology, Kanpur. It geographically falls in the zone of sub-tropical climate. It is roughly situated between the latitudes $26.20^{\circ}$ to $28.36^{\circ}$ North and longitude $80^{\circ}$ to $90^{\circ}$ east to study the effect of spacing and nutrient

\section{Keywords}

Effect, Spacing, nutrients management, Yield, Yield attributes, Quality characters, Hirsutum cotton.

Article Info

Accepted:

30 July 2017

Available Online:

10 November 2017 management system on growth, yield attributes, yield, quality and economics of hirsutum cotton. The treatment combinations comprising with $\mathrm{T}_{1}-$ Control without fertilizer + normal spacing $(67.5 * 30 \mathrm{~cm}), \mathrm{T}_{2}-100 \% \mathrm{RDF}+$ normal Spacing, $\mathrm{T}_{3}-100 \% \mathrm{RDF}+25 \%$ less than normal spacing, $\mathrm{T}_{4}-125 \% \mathrm{RDF}+25 \%$ less than normal spacing, $\mathrm{T}_{5}-125 \% \mathrm{RDF}+25 \%$ less than normal spacing + soil application of $\mathrm{ZnSO}_{4}, \mathrm{~T}_{6}-125 \% \mathrm{RDF}+25 \%$ less than normal spacing + foliar spray of $2 \%$ urea and $2 \%$ DAP, $\mathrm{T}_{7}-125 \% \mathrm{RDF}+25 \%$ less than normal spacing + foliar spray of $\mathrm{MgSO}_{4}$ and $\mathrm{ZnSO}_{4}$. The treatments were evaluated in Randomized Block Design with three replications. The normal spacing was kept row to row distance of 67.5 $\mathrm{cm}$ and plant to plant distance of $30 \mathrm{~cm}$. Crop was fertilized as per respective treatments where half of nitrogen and full dose of phosphorus and potassium was applied at the time of sowing and remaining half of nitrogen was applied in two equal installment one at 30 days after sowing and second at 60 days after sowing. Harvesting was done on the basis of picking when boll was fully open. Application of $125 \% \mathrm{RDF}+25 \%$ less than normal spacing + foliar spray of $2 \%$ urea and 2\% DAP produced significantly highest growth characters viz., plant height at 30,60, 90 and 150 days after sowing, number of monopopdia and sympodia, fresh and dry weight/plant, yield attributes viz., number of bolls $/ \mathrm{m}^{2}$, number of bolls/plant and boll weight, yield viz., seed cotton, lint, seed and stick, quality characters viz., ginning out tern, span length, micronaire value, uniformity ratio and fiber strength it was closely followed by $125 \% \mathrm{RDF}+$ $25 \%$ less than normal spacing + foliar spray of $\mathrm{MgSO}_{4}$ and $\mathrm{ZnSO}_{4}$. On the basis of above results, it may be concluded that hirsutum cotton genotype $\mathrm{H}-1300$ along with application of $125 \%$ recommended dose of fertilizers $(60: 30: 20 \mathrm{~kg} \mathrm{NPK} / \mathrm{ha})+25 \%$ less than normal spacing + foliar spray of $2 \%$ urea and $2 \%$ DAP was most productive and remunerative for cotton under Central Plain Zone of U.P. 


\section{Introduction}

Cotton is one of the most commercial crops of the world and in the maintaining of many economics. Cotton is cultivated in nearly 100 countries with China, India, United States, Pakistan and Brazil being the five largest producers of cotton. Cotton is the back born of textile industry and provides raw material in the form of lint to the textile industry. It is also grown in tropical and subtropical regions of more than 80 countries the world over. All the domesticated species of cotton suitable for commercial cultivation have been classified into two categories, new world cotton and old world cotton. The new world cotton has further been divided in to two groups based on fiber properties. The two old world diploid the species $G$. arboreum is most widely grown and cultivated commercially in India, Pakistan and other parts of South East Asia, primarily on dry and unproductive regions of Bangladesh, Berma, China, Sri Lanka, Viclnam et al., (Singh and Narayanan, 1991). The samples of fabric found in the excavation at Mohenjendaro suggest the manufacture of cotton textile in India was since 5000 years ago. Cotton is the most important crop in India and plays a dominant role in the industrial and economy of the country. The demand of textile market depends upon the quality of cotton fiber and governs by compound functions of mean fiber length, fiber fineness, fiber maturity, fiber strength, combined with the physical components such as colour and to ash contents. Each of these parameters is very important in deciding the spin ability of yarn, acceptance of dyes strength of yarn, luster of fabrics and blending of yarn with other manmade fibers. The fineness, maturity, fiber strength are known to be affected by factors such as drought, nutrients, season, stage of harvest, pests and diseases (Naryadayya, 1960). American cotton recorded, on an average, significantly higher value for seed index and kernel per cent than that of desi cotton. The low productivity of cotton is on account of several reasons, which, monocropping, decline in soil fertility status, late sowings, pests and diseases are the major constraints. Soil properties and crop production are liable to change due to continuous cropping with long term fertilization (Mathur, 1997) and such studies recorded soil fertility depletion trends. Application of organic manures alone or with inorganic fertilizer helps to improve soil productivity and maintain soil fertility. Bt. Cotton hybrids and their scope for extensive coverage in the country in coming years. There is need for change in the nutrient management of Bt cotton hybrids (Venugopal, 2004). Bt cotton technology has been widely accepted by Indians across the country. Since it is first commercialization in 2002. Productivity of cotton can considerably be improved by approximate fertilizer management. Fulfillment of nutritional requirements of the crop is essential for achieving the higher yields and fiber quality (Kalaichelvi, 2009 and Kumar et al., 2011). Response of cotton to applied nutrients is governed by environment and cultural factors. Among the various agriculture input, fertilizer have been found to better responsive to the cotton production. So, adequate fertilizer is essential to achieve the potential yield of cotton. However optimum fertilizer dose varies with soil and agro climate condition. It is obvious that the production and productivity of cotton can be improved by introduction of higher yielding genotypes coupled with suitable agronomic practices like maintenance of optimum/ideal plant density. Use of optimum dose of fertilizers and timely control of insect pest as well as proper weed and water management Practices. Application of micronutrients through foliar application has shown importance for their efficient utilization of better performance of crop (Rathinavel et al., (1999). It also regulates the biochemical 
changes in seed and increase yield of cotton (Chaudhary et al., 2001). Squaring, blooming and boll development are stages where cotton makes highest nutrients demand. Augmentation of nutrient supply through foliar application at such critical stages may increase yield of cotton (Bhatt and Nathu, 1986). Therefore the objective of this experiment was to standardize the spacing and nutrient management for growth parameters, yield \&yield attributes and Quality characters(i. e. number of plants/plot, plant height, Monopodia, Sympodia and number of plants/ha at harvest, fresh weight, dry weight, No. of Balls/ plant, No. of bolls/ $\mathrm{m}^{2}$ and ball weight, Ginning out turn, Micronaire value, Uniformity ratio, Fiber strength, Seed cotton yield, Lint yield, Cotton seed yield and Stick yield)respectively.

\section{Materials and Methods}

A field experiment was conducted, with hirsutum cotton genotype H-1300 during Kharif season 2015 at the Oil Seed Farm of C.S. Azad University of Agriculture and Technology, Kanpur, It is roughly situated between the latitudes $26.20^{\circ}$ to $28.36^{0}$ North and longitude $80^{\circ}$ to $90^{\circ}$ East in the zone of sub-tropical climate. The total annual rainfall of the year was $650.6 \mathrm{~mm}$ comprising generally from the middle of June and ending the second week of September. Occasional showers were also received from the SouthWest mansoon during winter. To study the effect of spacing and nutrient management system on growth, yield attributes, yield, and quality of hirsutum cotton. The seven treatment combinations comprising with $\mathrm{T}_{1}$ Control without fertilizer + normal spacing $(67.5 * 30 \mathrm{~cm}), \mathrm{T}_{2}-100 \% \mathrm{RDF}+$ normal Spacing, $\mathrm{T}_{3}-100 \% \mathrm{RDF}+25 \%$ less than normal spacing, $\mathrm{T}_{4}-125 \% \mathrm{RDF}+25 \%$ less than normal spacing, $\mathrm{T}_{5}-125 \% \mathrm{RDF}+25 \%$ less than normal spacing + soil application of $\mathrm{ZnSO}_{4}, \mathrm{~T}_{6}-125 \% \mathrm{RDF}+25 \%$ less than normal spacing + foliar spray of $2 \%$ urea and $2 \%$ DAP, $\mathrm{T}_{7}-125 \% \mathrm{RDF}+25 \%$ less than normal spacing + foliar spray of $\mathrm{MgSO}_{4}$ and $\mathrm{ZnSO}_{4}$. The treatments were evaluated in Randomized Block Design with three replications. The soil is generally sandy loam with moderated fertility. The determination of mechanical and chemical composition of the soil and its fertility status, the soil of experimental field was sandy loam in texture having $\mathrm{pH}$ 7.8. The fertility status of field was low in organic carbon $(0.48 \%)$ and medium in available phosphorus $(16 \mathrm{~kg} / \mathrm{ha})$ and available potash $(183 \mathrm{~kg} / \mathrm{ha})$. The cotton crop was sown on 28.05.2015 and harvested on 25-10-2015 and 10-11-2015 as first and second picking, respectively. The normal spacing was kept row to row distance of $67.5 \mathrm{~cm}$ and plant to plant distance of $30 \mathrm{~cm}$. Crop was fertilized as per respective treatments where half of nitrogen and full dose of phosphorus and potassium was applied at the time of sowing and remaining half of nitrogen was applied in two equal installment one at 30 days after sowing and second at 60 days after sowing. Optimum plant protection measures were adopted and applied insecticides as per need of crops. Observations are taken on growth characters yield and yield attributes quality characters. Harvesting was done on the basis of picking when bolls were fully opened. The fineness, maturity, fiber strength are known to be affected by factors such as drought, nutrients, season, stage of harvest, pests and diseases (Naryadayya, 1960). Productivity of cotton can considerably be improved by approximate fertilizer management. Fulfillment of nutritional requirements of the crop is essential for achieving the higher yields and fiber quality (Kalaichelvi, 2009 and Kumar et al., 2011). Use of optimum dose of fertilizers and timely control of insect pest as well as proper weed and water management Practices. Application of micronutrients through foliar application has shown importance for their efficient 
utilization of better performance of crop (Rathinavel et al., 1999). It also regulate the biochemical changes in seed and increase yield of cotton (Chaudhary et al., 2001). Squaring, blooming and boll development are stages where cotton makes highest nutrients demand. Augmentation of nutrient supply through foliar application at such critical stages may increase yield of cotton (Bhatt and Nathu, 1986). The data were analyzed statistically by the computer. Statistical methods and test of significance appropriate to the design (Cochran and Cox, 1950) were applied to the data for magnitude of the effects revealed to be significant of the ' $F$ ' test in the analysis of variation, summary tables giving the mean of treatment along with their standard errors were prepared. Appropriate critical differences were computer to test the significance between two treatments. Critical difference (CD) values at $P=0.05$ were used to determine the significance of differences between means.

\section{Results and Discussion}

Growth characters viz., number of plants, plant height at 30,60, 90, 120 and 150 days after sowing, number of sympodial and monopodial branches/plant, fresh and dry weight/plant of cotton was significantly influenced with different spacing and nutrient management systems increased with increasing doses of fertilizers. Application of $125 \%$ recommended dose of fertilizers $+25 \%$ less than normal spacing+ foliar spray of $2 \%$ urea 2\% DAP significantly increased plant height of cotton at all the physiological stages of crop growth as compared to rest of the doses of spacing and nutrient management.

Increasing plant height of cotton with spacing and nutrient management has been reported by Kaur et al., (2010) and Sharma et al., (2004). Higher plant height recorded in closer spacing was due to congestion in the growing crop plants with reduces more vertical growth and later spaced was restricted (Reddy and Kumar, 2010).

Significantly higher number of monopodia plant was obtained with the application $125 \%$ recommended dose of fertilizers $+25 \%$ less than normal spacing+ foliar spray of $2 \%$ urea and $2 \%$ DAP as compared to rest of the levels of spacing and nutrient management. Increasing dose of fertilizers with wider spacing increased number of sympodial branches/plant of cotton however, it could rest reached to the level of significance. The increased in monopodial and sympodia might be due to the fact the optimum nutrient helped in cell division and cell elongation leading to increased number of lateral branches. These results are close conformity with the findings of Ram and Giri (2006) and Kaur et al., (2010).

Increasing dose of fertilizers at wider spacing significantly influenced fresh and dry weight/plant of cotton. Significantly highest fresh and dry weight/plant was produced with the application of $125 \%$ RDF $+25 \%$ less than normal spacing+ foliar spray of $2 \%$ urea and $2 \%$ DAP as compared to lower doses of fertilizers with wider spacing. Application of $125 \% \mathrm{RDF}+25 \%$ less than normal spacing+ foliar spray of $\mathrm{MgSO}_{4}+\mathrm{ZnSO}_{4}$ significantly increased fresh and dry weight/plant of cotton as compared to lower levels of nutrient management with normal spacing. The increase in fresh and dry weight of plant might be due to increase in meristematic activity of plant. Similar results have also been reported by Jadhav et al., (2012).

Application of $125 \%$ RDF $+25 \%$ less than normal spacing+ foliar spray of $2 \%$ urea and $2 \%$ DAP significantly increased number of bolls/plant, number of boll $/ \mathrm{m}^{2}$ and boll weight of cotton as compared to lower doses of fertilizers and normal spacing. Significantly 
higher number of bolls/plant and boll weight of cotton was obtained with $125 \% \mathrm{RDF}+25 \%$ less than normal spacing+ foliar spray of $\mathrm{MgSO}_{4}+\mathrm{ZnSO}_{4}$ than the other treatments. The increase in number of bolls/plant, number of boll $/ \mathrm{m}^{2}$ and boll weight of cotton might be due to the fact that increase in growth attributes viz., plant height, number of monopodial and sympodial branches, fresh and dry weight of cotton. These findings are corroborate with the results of Jadhav et al., (2012).

Table.1A Effect of spacing and nutrients management on growth parameters, in hirsutum cotton

\begin{tabular}{|c|c|c|c|c|c|c|c|}
\hline \multirow[t]{2}{*}{ Treatments } & \multirow{2}{*}{$\begin{array}{l}\text { No. of } \\
\text { plants/ } \\
\text { plot }\end{array}$} & \multirow{2}{*}{$\begin{array}{l}\text { No. of } \\
\text { plant } \\
\text { popula } \\
\text { tion/ha }\end{array}$} & \multicolumn{5}{|c|}{ Plant height (cm) } \\
\hline & & & $\begin{array}{c}30 \\
\text { DAS }\end{array}$ & $\begin{array}{c}\text { 60 } \\
\text { DAS }\end{array}$ & $\begin{array}{c}90 \\
\text { DAS }\end{array}$ & $\begin{array}{c}120 \\
\text { DAS }\end{array}$ & $\begin{array}{c}150 \\
\text { DAS }\end{array}$ \\
\hline $\begin{array}{l}\text { T1 - Control without fertilizer + } \\
\text { normal spacing }\end{array}$ & 62.33 & $\begin{array}{l}38476 . \\
7\end{array}$ & 25.00 & 47.67 & 68.20 & 93.80 & $\begin{array}{c}109.9 \\
3\end{array}$ \\
\hline $\mathrm{T} 2-100 \% \mathrm{RDF}+$ normal Spacing & 73.33 & $\begin{array}{c}45308 . \\
7\end{array}$ & 27.47 & 50.00 & 73.87 & 97.93 & $\begin{array}{c}117.5 \\
3\end{array}$ \\
\hline $\begin{array}{l}\mathrm{T} 3-100 \% \text { RDF }+25 \% \text { less than } \\
\text { normal spacing }\end{array}$ & 65.33 & $\begin{array}{c}39683 . \\
3\end{array}$ & 28.00 & 51.13 & 72.40 & 96.53 & $\begin{array}{c}114.8 \\
0\end{array}$ \\
\hline $\begin{array}{l}\mathrm{T} 4-125 \% \mathrm{RDF}+25 \% \text { less than } \\
\text { normal spacing }\end{array}$ & 76.33 & $\begin{array}{c}41285 . \\
0\end{array}$ & 29.80 & 51.80 & 74.20 & 99.40 & $\begin{array}{c}118.1 \\
3\end{array}$ \\
\hline $\begin{array}{l}\mathrm{T}_{5}-125 \% \mathrm{RDF}+25 \% \text { less than } \\
\text { normal spacing }+ \text { Soil application of } \\
\mathrm{ZnSO}_{4}(20 \mathrm{~kg} / \mathrm{ha})\end{array}$ & 77.33 & $\begin{array}{l}45285 . \\
0\end{array}$ & 30.20 & 52.73 & 75.13 & $\begin{array}{c}101.1 \\
3\end{array}$ & $\begin{array}{c}120.2 \\
3\end{array}$ \\
\hline $\begin{array}{l}\mathrm{T} 6-125 \% \mathrm{RDF}+25 \% \text { less than } \\
\text { normal spacing }+ \text { foliar spray of } 2 \% \\
\text { urea \& } 2 \% \text { DAP }\end{array}$ & 80.00 & $\begin{array}{c}50724 . \\
3\end{array}$ & 31.60 & 56.00 & 77.47 & $\begin{array}{c}105.2 \\
0\end{array}$ & $\begin{array}{c}124.6 \\
0\end{array}$ \\
\hline $\begin{array}{l}\mathrm{T}_{7}-125 \% \mathrm{RDF}+25 \% \text { less than } \\
\text { normal spacing }+ \text { foliar spray of } \\
\mathrm{MgSO}_{4}(1 \%) \text { and } \mathrm{ZnSO}_{4}(0.5 \%)\end{array}$ & 78.00 & $\begin{array}{c}48504 . \\
3\end{array}$ & 30.26 & 55.27 & 76.13 & $\begin{array}{c}102.3 \\
3\end{array}$ & $\begin{array}{c}122.1 \\
3\end{array}$ \\
\hline S.E(d) \pm & 0.74 & 363.57 & 0.62 & 1.14 & 0.83 & 0.63 & 1.62 \\
\hline C.D. at $5 \%$ & 1.61 & 792.15 & 1.34 & 2.48 & 1.82 & 1.37 & 3.52 \\
\hline
\end{tabular}

Table.1B Effect of spacing and nutrients management on growth parameters, in hirsutum cotton

\begin{tabular}{|c|c|c|c|c|}
\hline Treatments & $\begin{array}{c}\text { Monopodia } \\
\text { /plant }\end{array}$ & $\begin{array}{c}\text { Sympodia } \\
\text { /plant }\end{array}$ & $\begin{array}{c}\text { Fresh } \\
\text { weight/plant }\end{array}$ & $\begin{array}{c}\text { Dry } \\
\text { weight/plant }\end{array}$ \\
\hline T1 - Control without fertilizer + normal spacing & 0.87 & 12.00 & 274.33 & 136.33 \\
\hline $\mathrm{T} 2-100 \% \mathrm{RDF}+$ normal Spacing & 1.07 & 12.67 & 335.67 & 150.00 \\
\hline $\mathrm{T} 3-100 \% \mathrm{RDF}+25 \%$ less than normal spacing & 0.93 & 13.00 & 333.33 & 145.33 \\
\hline $\mathrm{T} 4-125 \% \mathrm{RDF}+25 \%$ less than normal spacing & 1.00 & 13.10 & 337.33 & 152.00 \\
\hline $\begin{array}{l}\mathrm{T}_{5}-125 \% \mathrm{RDF}+25 \% \text { less than normal spacing }+ \text { Soil } \\
\text { application of } \mathrm{ZnSO}_{4}(20 \mathrm{~kg} / \mathrm{ha})\end{array}$ & 1.40 & 13.20 & 346.67 & 153.00 \\
\hline $\begin{array}{l}\mathrm{T} 6-125 \% \mathrm{RDF}+25 \% \text { less than normal spacing }+ \\
\text { foliar spray of } 2 \% \text { urea \& } 2 \% \text { DAP }\end{array}$ & 1.13 & 13.47 & 388.67 & 158.33 \\
\hline $\begin{array}{l}\mathrm{T}_{7}-125 \% \mathrm{RDF}+25 \% \text { less than normal spacing }+ \\
\text { foliar spray of } \mathrm{MgSO}_{4}(1 \%) \text { and } \mathrm{ZnSO}_{4}(0.5 \%)\end{array}$ & 1.23 & 13.27 & 349.00 & 155.67 \\
\hline S.E(d) \pm & 0.08 & 0.11 & 3.56 & 2.25 \\
\hline C.D. at $5 \%$ & 0.17 & 0.24 & 7.76 & 4.89 \\
\hline
\end{tabular}


Table.2 Effect of spacing and nutrients management on yield attributes, yield attributes in hirsutum cotton

\begin{tabular}{|c|c|c|c|}
\hline Treatments & No. of bolls/plant & No. of bolls $/ \mathrm{m}^{2}$ & Bolls weight (g) \\
\hline T1 - Control without fertilizer + normal spacing & 13.93 & 66.06 & 3.13 \\
\hline $\mathrm{T} 2-100 \% \mathrm{RDF}+$ normal Spacing & 17.80 & 89.33 & 3.25 \\
\hline $\mathrm{T} 3-100 \% \mathrm{RDF}+25 \%$ less than normal spacing & 15.87 & 80.76 & 3.25 \\
\hline $\mathrm{T} 4-125 \% \mathrm{RDF}+25 \%$ less than normal spacing & 19.53 & 95.13 & 3.26 \\
\hline $\begin{array}{l}\mathrm{T}_{5}-125 \% \mathrm{RDF}+25 \% \text { less than normal spacing }+ \text { Soil } \\
\text { application of } \mathrm{ZnSO}_{4}(20 \mathrm{~kg} / \mathrm{ha})\end{array}$ & 21.13 & 98.52 & 3.33 \\
\hline $\begin{array}{l}\text { T6 }-125 \% \text { RDF }+25 \% \text { less than normal spacing }+ \text { foliar spray of } \\
2 \% \text { urea \& } 2 \% \text { DAP }\end{array}$ & 25.40 & 117.88 & 3.43 \\
\hline $\begin{array}{l}\mathrm{T}_{7}-125 \% \mathrm{RDF}+25 \% \text { less than normal spacing }+ \text { foliar spray of } \\
\mathrm{MgSO}_{4}(1 \%) \text { and } \mathrm{ZnSO}_{4}(0.5 \%)\end{array}$ & 23.47 & 102.29 & 3.39 \\
\hline S.E(d) \pm & 0.62 & 1.74 & 0.08 \\
\hline C.D. at $5 \%$ & 1.35 & 3.80 & 0.17 \\
\hline
\end{tabular}

Tables.3 Effect of spacing and nutrients management on yield and quality characters in hirsutum cotton

\begin{tabular}{|c|c|c|c|c|c|c|c|c|c|}
\hline Treatments & $\begin{array}{c}\text { Seed } \\
\text { cotton } \\
\text { yield } \\
(\mathrm{kg} / \mathrm{ha})\end{array}$ & $\begin{array}{c}\text { Lint } \\
\text { yield } \\
\text { (kg/ha) }\end{array}$ & $\begin{array}{l}\text { Cotton } \\
\text { seed } \\
\text { yield } \\
(\mathrm{kg} / \mathrm{ha}) \\
\end{array}$ & $\begin{array}{c}\text { Stick } \\
\text { yield } \\
\text { (kg/ha) }\end{array}$ & $\begin{array}{l}\text { Ginning } \\
\text { out turn } \\
(\%)\end{array}$ & $\begin{array}{c}\text { Span } \\
\text { length } \\
25 \% \\
(\mathbf{m m}) \\
\end{array}$ & $\begin{array}{l}\text { Micro } \\
\text { naire } \\
\text { value } \\
(\%)\end{array}$ & $\begin{array}{l}\text { Unifor } \\
\text { mity } \\
\text { ratio } \\
(\%)\end{array}$ & $\begin{array}{c}\text { Fiber } \\
\text { strength } \\
(\mathrm{g} / \mathrm{tax})\end{array}$ \\
\hline $\begin{array}{l}\text { T1 - Control without fertilizer + normal } \\
\text { spacing }\end{array}$ & 746.67 & 261.8 & 485.33 & 4384.0 & 35.02 & 26.7 & 4.77 & 80.0 & 25.47 \\
\hline T2 - 100\% RDF + normal Spacing & 1199.33 & 422.9 & 777.67 & 5142.7 & 35.20 & 25.6 & 4.30 & 80.0 & 26.23 \\
\hline $\begin{array}{l}\mathrm{T} 3-100 \% \mathrm{RDF}+25 \% \text { less than normal } \\
\text { spacing }\end{array}$ & 1144.00 & 404.2 & 740.33 & 4483.3 & 35.33 & 26.2 & 4.60 & 80.3 & 27.30 \\
\hline $\begin{array}{l}\mathrm{T} 4-125 \% \mathrm{RDF}+25 \% \text { less than normal } \\
\text { spacing }\end{array}$ & 1250.00 & 430.9 & 819.67 & 5504.3 & 34.47 & 25.4 & 4.63 & 80.0 & 28.30 \\
\hline $\begin{array}{l}\mathrm{T}_{5}-125 \% \mathrm{RDF}+25 \% \text { less than normal } \\
\text { spacing + Soil application of } \mathrm{ZnSO}_{4} \\
(20 \mathrm{~kg} / \mathrm{ha})\end{array}$ & 1257.00 & 429.9 & 827.67 & 5733.0 & 34.20 & 26.1 & 4.47 & 79.7 & 27.50 \\
\hline $\begin{array}{l}\mathrm{T} 6-125 \% \mathrm{RDF}+25 \% \text { less than normal } \\
\text { spacing }+ \text { foliar spray of } 2 \% \text { urea } \& 2 \% \\
\text { DAP }\end{array}$ & 1391.62 & 487.5 & 902.60 & 6388.7 & 35.63 & 26.2 & 4.83 & 80.0 & 26.37 \\
\hline $\begin{array}{l}\mathrm{T}_{7}-125 \% \mathrm{RDF}+25 \% \text { less than normal } \\
\text { spacing }+ \text { foliar spray of } \mathrm{MgSO}_{4}(1 \%) \\
\text { and } \mathrm{ZnSO}_{4}(0.5 \%)\end{array}$ & 1259.33 & 448.0 & 811.67 & 5818.7 & 35.60 & 25.5 & 4.43 & 80.0 & 27.70 \\
\hline S.E(d) \pm & 58.65 & 19.80 & 39.10 & 46.22 & 0.18 & 0.13 & 0.78 & 0.78 & 0.14 \\
\hline C.D. at $5 \%$ & 127.79 & 43.14 & 85.20 & 100.70 & 0.39 & 0.27 & NS & NS & 0.30 \\
\hline
\end{tabular}

Application of $125 \%$ recommended dose of fertilizers $+25 \%$ less than normal spacing+ foliar spray of $2 \%$ urea and $2 \%$ DAP increased significantly higher seed cotton yield to the extent of 86.38 per cent as compared to control without fertilizer with normal spacing. Significantly higher seed cotton yield was also produced with the application of $125 \% \mathrm{RDF}+25 \%$ less than normal spacing+ foliar spray of $\mathrm{MgSO}_{4}+$ $\mathrm{ZnSO}_{4}$ as compared to control. Application of higher doses of fertilizers i.e. $125 \%$ RDF $+25 \%$ less than normal spacing+ foliar spray of $\mathrm{MgSO}_{4}+\mathrm{ZnSO}_{4}$ significantly increased lint yield of cotton as compared to without nutrient management + normal spacing. Significantly higher lint yield of cotton was obtained with the application of $125 \% \mathrm{RDF}$ $+25 \%$ less than normal spacing+ foliar spray of $2 \%$ urea and $2 \%$ DAP as compared to rest of the levels of nutrient spacing. Significantly higher cotton seed yield of cotton was 
produced with the application of $125 \%$ recommended dose of fertilizer $+25 \%$ less than normal spacing+ foliar spray of $\mathrm{MgSO}_{4}$ $+\mathrm{ZnSO}_{4}$ as compared to control. Application of $125 \%$ recommended dose of fertilizers produced $+25 \%$ less than normal spacing+ foliar spray of $2 \%$ urea $2 \%$ DAP significantly highest stick yield of cotton was obtained as compared to rest of the doses of fertilizers with spacing. The minimum seed cotton, lint, seed and stick yield of cotton in obtained with control without fertilizer + normal spacing. The increased in yields (seed cotton, lint, seed and stick) of cotton with the application of higher doses of fertilizers might be due to increase in growth and yield attributing characters of cotton. Similar observations were made by Bhattoo et al., (2012). Raskar (2004) reported that progressive increase in fertilizer levels from 50 to 100 per cent RDF resulted in the significant increase in seed cotton yield. The yield increase by application of 100 per cent RDF was 31.71 and 10.16 per cent higher over 50 and 75 per cent RDF, respectively. The overall improvement in yield attributing characters was responsible for higher cotton yield in increasing levels of fertilizers. Kote et al., (2005) reported that the application of 100 per cent of recommended dose of fertilizers produced significantly higher seed cotton yield and cotton seed yield of cotton as compared to 75 per cent and 50 per cent recommended dose of fertilizers. Those results are in accordance with the findings of Bhaskar (1993). Significant increase seed cotton yield at a wider spacing have been reported by kumar et al., (2010).

Application of different nutrient management system significantly influenced on quality characters viz., ginning out turn, span length, fiber strength, micronaire value and uniformity ratio of cotton. Application of 125 percent of recommended dose of fertilizers $+25 \%$ less than normal spacing+ foliar spray of $\mathrm{MgSO}_{4}+\mathrm{ZnSO}_{4}$ produced significantly more ginning out turn of cotton as compared to rest of the doses of nutrient management with spacing. Significantly higher ginning out turn was also recorded with the application of 125 per cent recommended dose of fertilizers $+25 \%$ less than normal spacing than the other treatments. Span length of cotton was significantly increased in control without fertilizer + normal spacing as compared to rest of the treatment combinations. Significantly higher span length of cotton was also recorded with the application of 125 per cent recommended dose of fertilizers $+25 \%$ less than normal spacing than $125 \% \mathrm{RDF}+$ $25 \%$ less than normal spacing. Application of 125 per cent recommended dose of fertilizers $+25 \%$ less than normal spacing+ foliar spray of $2 \%$ and urea $2 \%$ DAP produced higher micronaire value and uniformity ratio of cotton followed by control without fertilizer + normal spacing. The minimum quality characters viz., ginning out turn, span length, micronaire value, uniformity ratio, fiber strength of cotton was obtained in without nutrient application + normal spacing. These results are in accordance with the results of Srinivasul et al., (2008.Rao and Janawade (2009) reported that the ginning out turn and lint index was incurred with the application 100 per cent of recommended dose of fertilizers followed by 75 per cent RDF and 50 per cent RDF (Tables 1-3).

On the basis of above results, it may be concluded that hirsutum cotton genotype $\mathrm{H}-$ 1300 along with application of $125 \%$ recommended dose of fertilizers $(60: 30: 20 \mathrm{~kg}$ $\mathrm{NPK} / \mathrm{ha})+25 \%$ less than normal spacing + foliar spray of $2 \%$ urea and 2\% DAP was most productive and remunerative for cotton under Central Plain Zone of U.P.

\section{References}

Bhaskar, K.S., Gaikwad, S.T. and Kumari, P.A. 1993. Response of upland cotton 
(Gossypium hirsutum L.) to the levels of fertilizers in shallow soils of watershed near Nagpur. Indian J. Agron., 38(1): 89-92.

Bhatt, J. G., and Nathu, A.R.S. 1986. Simple measures of reducing losses of buds and bolls in cotton. J. Cotton Res. Dev. 16: 18-20.

Bhattoo, M.S., Mehta, Anil, Kumar, Mahesh, Yadav, N.K., Nirania, K.S. and Sethi, G.S. 2012. Influence of high density plant population and fertilizer levels in seed cotton yield of American cotton. In proceeding.... p. 39.

Chaudhary, C.S., Pawar, W.S., Mendhe, S.N., Nikkam, R.R. and Ingole, A.S. 2001. Effect of land configuration and nutrient management on yield of rainfed cotton. J. Soil Crops 11: 125-127.

Cochran, W.B., and Cox, G.M. 1950. "Experimental design". John Wiley \& Sons, Inc., New york ( $1^{\text {st }}$ edn).

Devraj, Bhattoo, M.S., Duhan, B.S., KumariPromila and Jain, P.P. 2011. Effect of crop geometry and fertilizer levels on seed cotton yield and nutrient uptake of $\mathrm{Bt}$ cotton under Nitrogen condition. J. Cotton Res. Dev. 25 (2): 176-180.

Jadhav, S.G., Chavan, D.A., Gokhalem D.N., and Dadgale, P.R. 2012. Response of Bt cotton to different spacing, growth regulator and nutrient management. In proceeding of international symposium on 'Global cotton production technologies vis- a-vis climate change' pp. 45.

Kalaichelic, K., 2009. BT cotton response to plant geometry and fertilizer levels. J. Cotton Res. Dev. 23(1): 96-99

Kaur, Parminder, Kaur, Moninder, Gill, M.S. and Buttar, G.S. 2010. Response of Bt cotton hybrid $\mathrm{RCH} 134$ to varied spacing and fertility levels under Punjab conditions. J. Cotton Res. Dev., 24(2): 189-192.
Kote, G.M., Giri, A.M. and Kawsale, S.P. 2005. Nutrient concentration and uptake of different cotton (Gossypium hirsutum) genotypes as influence by intercrops and fertilizers levels under rainfed conditions. J. Cotton Res. Dev. 19(2): 188-190.

Kumar, Jagdish Yadav, M.P., Kushwaha, S.P. and Kumar, Nand 2010. Effect of different spacing and potassium levels on yield attributes, yield and economics of hirsutum cotton. J. Cotton Res. Dev. 24(2) 208-209

Kumar, Mandeep, Pannu, R.K., Nehra, D.S. and Dhaka, A.K. 2011. Effect of spacing and fertilizer on growth, yield and quality of different cotton genotypes. J. Cotton Res. Dev. 25 (2) 236-239.

Mathur, G.M., 1997. Effect of long term application of fertilizers and manures on soil properties and yield under cottonwheat rotation in north-west Rajasthan, J. Indian Soc. Soil Sci., 45: 288-292.

Nanjudayya, 1960. Technology in cotton in India. Monograph Published by: I.C.C. Mumbai pp. 45-70.

Pendharker, A.B., Solunke, S.S., Lambade, B.M., Nawale, S.S. and Dalvai N.D. 2010. Response of Bt cotton Hybrids to different plant spacing under rained conditions. J. Cotton Res. Dev. 24 (2) 216-218.

Ram, M., and Giri, A.N. 2006. Response of newly released cotton ( $G$. hirsutum) varieties to plant densities and fertilizer levels. J. Cotton Res. Dev., 20: 85-86.

Rao, Satyanarayana and Janawade, A.D. 2009. Nutrients uptake and fiber quality parameters as influenced by integrated nutrient management practices in irrigated hybrid cotton. J. Cotton Res. Dev., 23(1): 237-239.

Raskar, B.S., 2004. Effect of irrigation methods, fertilizer levels and green manuring on yield and nutrient balance 
in summer cotton. J. Cotton Res. Dev., 18(2): 180-183.

Rathinavel, K., Dharanelingam, S. and Panare Selvam, S. 1999. Effects of micronutrients on productivity and quality of cotton and cotton seed. Madras agric. J. 86: 313-316.

Reddy, P., Raghu Ram and Kumar, B. Dileep 2010. Spacing Studies in genetically modified cotton. J. Cotton Res. Dev. 24 (2) 219-220.

Sharma, R.K., 2004. Production potential of cotton as affected by various spacing and fertility levels. J. cotton Res. Dev. 18-187-188

Solunke, P.S., and Fatak, Sangita, U. 2010. Effect of organic manures, inorganic fertilizers and plant protection on quality and economics of desi cotton. $J$.
Cotton Res. Dev., 24(2): 174-181.

Srinivasula, K., Hema, K., Narayan, E., Prasad, N.V.V.S.D. and Rao, N.H.P. 2007. Agronomic evaluation of $\mathrm{Bt}$ Hybrids (NCS $207 \mathrm{Bt}$ ) in Vertisols of Andhra Pradesh under Ramble conditions. J. Cotton Res. Dev. 21 191193

Venugopal, K., 2004. Changing paradigms (avenues/approaches) in cotton production technology for improving productivity and fiber quality of cotton. International Symposium on Strategies for Sustainable crop production- A global vision held at University of Agricultural Sciences Dharwad, Karnataka (India) from November 2325 pp. 1-6.

\section{How to cite this article:}

Avinash Kumar Singh, Jagdish Kumar, Rajeev Kumar, Sudhir Kumar and Sunil Kumar. 2017. Effect of Spacing and Nutrients Management on Growth, Yield, Yield Attributes and Quality Characters in Hirsutum Cotton" of Central Plain Zone of U.P. Int.J.Curr.Microbiol.App.Sci. 6(11): 5358-5366. doi: https://doi.org/10.20546/ijcmas.2017.611.512 